\title{
Engineering method for calculating the parameters of flue gas parameters of coal-fired thermal power plants based on solid fuel characteristics
}

\author{
Igor Volchyn ${ }^{1}$, Liudmyla Haponych ${ }^{2}$
}

\author{
1 - Coal Energy Technology Institute, Kyiv, Ukraine \\ 2 - National University of Food Technologies, Kyiv, Ukraine
}

Keywords:

Power

Industry

Environment

Thermal

Flue gas

Emission

Sulfur dioxide

Article history:

Received

29.09.2016

Received in

revised form

30.11.2016

Accepted

30.12.2016

Corresponding

author:

Liudmyla

Haponych

E-mail:

haponych@ukr.net

DOI:

10.24263/2310-

1008-2016-4-2-14

\section{Abstract}

Introduction. The increase in coal share in the fuel balance of thermal power plants has led to increasing the $\mathrm{SO}_{2}$ annual gross emissions to about 1 million tons. This fact require to introduce technological measures for the reduction of $\mathrm{SO}_{2}$ emission at coalfired thermal power plants.

Materials and Methods. Using a standard procedure, we have performed calculations of the specific flue gases volumes and $\mathrm{SO}_{2}$ concentrations in them by the data of 96 certificates for coal products from mines and concentrating plants of the Donetsk coal basin.

Results and Discussion. As a result, we have obtained empirical linear dependences of the specific volume of dry flue gases on lower heating value and ash content in the fuel and dependences of $\mathrm{SO}_{2}$ concentration on sulfur and ash content in the fuel, which are different for low-reactive and high-reactive coals. In the case of presence of unburned carbon, the specific volume of dry flue gases decreases by a factor of $\left(1-q_{\mathrm{u}} / 100\right)$, and $\mathrm{SO}_{2}$ concentration in them increases in the same proportion.

We have created an engineering method for determining the specific volume of dry flue gases of coal-fired boilers and expected $\mathrm{SO}_{2}$ concentration in them based on the data of coal technical analysis in the presence of the heat loss due to unburnt carbon. The method of the specific emissions' calculation at the TPPs and CHPs and the sulphur dioxide concentration expected in it is proposed to use in a range of the fuel ash content $A^{d}$ from 4.0 to $50.0 \%$ and the fuel low heat value $Q_{i}^{r}$ from 14.5 to $32.0 \mathrm{MJ} / \mathrm{kg}$.

The proposed engineering method has been used for calculating an estimate of the gross $\mathrm{SO}_{2}$ emissions and volumes of dry flue gases at the Ukrainian coal-fired thermal power plants from 2012 to 2016 . The values of sulfur specific emission in flue gases during recent years are at a level of 16-20 grams per kilowatt-hour (kW-h) of electricity supplied.

Conclusions. The method developed allows to make the evaluation of the sulphur dioxide emission expected on the basis of the technical analysis data and choose necessary desulphurization technology to meet the environment legislation requirements. 


\section{Introduction}

The problem of emissions reduction of contaminants from flue gas formed by burning of solid fuels at Thermal Power Plants (TPPs) and Combined Heat and Power Plants (CHPs) is of large environmental, technological, and economical importance. In recent years, $90 \%$ of $\mathrm{SO}_{2}$ emission in Ukraine falls on thermal power industry. The coal share increasing in fuel balance of TPPs to $98 \%$ and in fuel balance of large-scale CHPs' to $20 \%$ led to increasing of the $\mathrm{SO}_{2}$ annual gross emissions to near 1 million tons [1]. The current $\mathrm{SO}_{2}$ permissible emissions standards are practically determined on the basis of the fuel quality that is supplied to the TPPs of Ukraine, and the burning technology. The emission limit values of $\mathrm{SO}_{2}$ from the large existing coal-dust boilers are 3400 milligrams per cubic meter under normal conditions $\left(0{ }^{\circ} \mathrm{C}\right.$ and $\left.101.325 \mathrm{kPa}\right)$ and $6 \%$ oxygen content in dry gas $\left(\mathrm{mg} / \mathrm{m}_{\mathrm{n}}{ }^{3}\right)$ for anthracite (A), $4500 \mathrm{mg} / \mathrm{m}_{\mathrm{n}}{ }^{3}$ for semi-anthracite (SA) and $5100 \mathrm{mg} / \mathrm{m}_{\mathrm{n}}{ }^{3}$ for bituminous (B), subbituminous (SB) coal and lignite. For solid fuel combustion in the circulating fluidized bed, the emission limit value of the sulfur dioxide is $400 \mathrm{mg} / \mathrm{m}_{\mathrm{n}}{ }^{3}$.

The current permissible $\mathrm{SO}_{2}$ emission limit values are valid until December, 31, 2017. The Ukraine as a Member of the Energy Community should provide since January, 1, 2018 the compliance of the output sulfur dioxide concentration in the flue gas from the existing coal-fired TPPs and CHPs not more than $400 \mathrm{mg} / \mathrm{m}_{\mathrm{n}}{ }^{3}$, but for new power units -200 $\mathrm{mg} / \mathrm{m}_{\mathrm{n}}{ }^{3}$ as required by the Directive 2001/80/EU. Nowadays, the level of the $\mathrm{SO}_{2}$ emissions at TPPs of Ukraine exceeds these limit values in 5-17 times [1]. The payment for $\mathrm{SO}_{2}$ emissions exceeded 1.2 billion UAH (106.5 million USD) in 2014, 1.6 billion UAH (74 million USD) in 2015 and 2.0 billion UAH (76.8 million USD) in 2016.

Besides, the Ukraine's economy bears huge social and economic losses due to deterioration of the health status of the population living at the territories adjacent to the coal-fired boilers, and continuous increase of costs for health care. Contaminants emission will lead to significant increase of general level of mortality. It will increase the number of cardio-pneumatic diseases and lung cancer to $68 \%$ of total mortality from all diseases (according to the International Centre for Policy Studies). According to the estimates of World Health Organization, increase of average $\mathrm{SO}_{2}$ daily concentration in the atmosphere by $10 \mu \mathrm{g} / \mathrm{m}^{3}$ leads to an increase in the total mortality by $0.6 \%$, from respiratory diseases for $1.2 \%$, from heart diseases - for $0.6 \%$. In 2012, about 3.7 million additional events of the death are connected with air pollution from the stationary sources. The level of the additional deaths due to air pollution in Ukraine reaches 30 thousand persons per year, and following our estimates, the number of the additional deaths due to pollution by $\mathrm{SO}_{2}$ reaches 11 thousand people per year.

In Ukraine, the annual volume of the direct medical costs for treatment due to diseases caused by air pollution exceeds 125 million USD (according to the International Centre for Policy Studies). Taking into account the negative influence of the $\mathrm{SO}_{2}$ on human health and environment, introduction of the measures to reduce sulfur dioxide emissions at TPPs and CHPs is necessary.

Thus, the interest is the issue of the assessment of $\mathrm{SO}_{2}$ output concentration in dry flue gas based on the fuel characteristics. This will select the sources of supply of coal of the need quality into power plant and choose the desulphurization technology.

The purpose of this work was to develop an engineering method creation to calculate specific dry flue gas volumes at TPPs and CHPs and the sulfur dioxide concentration expected in the flue gas. 


\section{Materials and methods}

The expected specific volume of flue gas and sulfur dioxide concentration can be calculated according to the standard method (it can be found in Teplovoi raschet kotel'nykh agregatov - Normativnyi metod (1998); Metodika opredeleniya valovykh vybrosov zagryaznyayushchikh veshchestv v atmosferu ot kotel'nykh ustanovok TES. RD 34.02.30598, Moskva, VTI (1998); HKD 34.02.305-2002. Vykydy zabrudnyuyuchykh rechovyn v atmosferne povitrya vid enerhetychnykh ustanovok. Metodyka vyznachennya (2002)) at known elemental composition of the coal (as received) - mass parts of moisture $\gamma_{W}$, ash $\gamma$, sulfur (organic and pyritic) $\gamma_{S}$, carbon $\gamma_{C}$, hydrogen $\gamma_{H}$, oxygen $\gamma_{O}$ and nitrogen $\gamma_{N}$. The sulfate sulfur is a part of ash of fuel.

The dry flue gas consists of carbon dioxide and sulfur dioxide as well as molecular nitrogen. The stoichiometric specific volume of dry flue gas $V_{G o d}, \mathrm{~m}_{\mathrm{n}}{ }^{3} \mathrm{~kg}$, in the case of full fuel burn-up and lack the absence of oxygen in them, is determined as:

$$
V_{\text {God }}=8.893 \gamma_{C}+20.9724 \gamma_{H}+3.319 \gamma_{S}-2.6424 \gamma_{O}+0.7997 \gamma_{N}
$$

A similar formula can be found in [2]. To ensure efficient fuel combustion, the combustion air is fed in excess. A certain amount of air enters into the boiler through leakages (the spurious suctions). The specific volume of dry flue gas $V_{G d}, \mathrm{~m}_{\mathrm{n}}{ }^{3} / \mathrm{kg}$, under normal conditions, at the known value of $\mathrm{O}_{2}$ content in them is determined by the formula (in the case of full fuel burn-up):

$$
V_{G d}=\frac{21}{21-O_{2}}\left(8.893 \gamma_{C}+20.9724 \gamma_{H}+3.319 \gamma_{S}-2.6424 \gamma_{O}+0.7997 \gamma_{N}\right)
$$

According to Directive 2001/80/EC, during the combustion of solid fuels, the $\mathrm{O}_{2}$ standard content in dry flue gas is $6 \%$. At this content, the first multiplier in formula (2) is $1.4[=21 /(21-6)]$.

The expected sulfur dioxide concentration $C_{S O 2}, \mathrm{mg} / \mathrm{m}_{\mathrm{n}}{ }^{3}$, in dry flue gas under normal conditions and standard $\mathrm{O}_{2}$ content (under conditions of full fuel burn-up) is determined as follows:

$$
C_{S O 2}=\frac{10^{6} \cdot 2 \gamma_{S}\left(1-\eta_{I}\right)\left(1-\eta_{I I} \beta\right)}{1.4\left(8.893 \gamma_{C}+20.9724 \gamma_{H}+3.319 \gamma_{S}-2.6424 \gamma_{O}+0.7997 \gamma_{N}\right)}
$$

where $\eta_{I}$ is the efficiency of the sulphur retention by ash (or by sorbent) in the boiler; $\eta_{I I}$ is the efficiency of the flue gas desulfurization plant, $\beta$ is the factor of the sulfur removal unit operation.

\section{Results and discussion}

For the coal-fired TPPs of Ukraine, the fuel heat losses through unburned gas species of fuel $q_{g}, \%$, are insignificant, less $0.1 \%$. The heat losses due unburnt carbon $q_{\mathrm{u}}, \%$, for the TPPs that burn high-reactive coals - bituminous (B) and subbituminous (SB) coals are $0.2-$ $1.8 \%$, and for the TPPs that burn low-reactive coals - anthracite (A) and semi-anthracite (SA) are 3.6-10.0\%. 


\section{- Processes and Equipment of Food Productions-}

The heat loss due unburnt carbon $q_{u} \%$, defines the carbon content in the fly ash and bottom ash by formula:

$$
q_{u}=100 \cdot \gamma_{A} \times\left(a_{f a} \cdot \frac{u_{f a}}{100-u_{f a}}+a_{s l} \cdot \frac{u_{s l}}{100-u_{s l}}\right) \times \frac{Q_{C}}{Q_{i}^{r}}
$$

where $a_{f a}$ is the part of fly ash in total ash; $u_{f a}$ is the carbon content in fly ash, $\%$; afa is the part of fly ash in total ash; ufa is the carbon content in fly ash, $\% ; Q_{i}^{r}$ is the lower heating value of the fuel, $\mathrm{MJ} / \mathrm{kg} ; Q_{C}$ is the heat of carbon conversion to $\mathrm{CO}_{2}$ which is $32.68 \mathrm{MJ} / \mathrm{kg}$.

The specific volume of dry flue gas under normal conditions and standard $\mathrm{O}_{2}$ content of with regard for the availability of mechanical unburnt carbon can be determined, as follows:

$$
V_{G d}\left(q_{u}\right)=1.4\left(8.893 \gamma_{C}\left(1-\frac{q_{u}}{100 \cdot \gamma_{C}} \cdot \frac{Q_{i}^{r}}{Q_{C}}\right)+20.9724 \gamma_{H}+3.319 \gamma_{S}-2.6424 \gamma_{O}+0.7997 \gamma_{N}\right)
$$

For calculation of the sulfur dioxide concentration in them, the expression is obtained:

$$
C_{S O 2}\left(q_{u}\right)=\frac{10^{6} \cdot 2 \gamma_{S}\left(1-\eta_{I}\right)\left(1-\eta_{I I} \beta\right)}{1.4\left(8.893 \gamma_{C}\left(1-\frac{q_{u}}{100 \cdot \gamma_{C}} \cdot \frac{Q_{i}^{r}}{Q_{C}}\right)+20.9724 \gamma_{H}+3.319 \gamma_{S}-2.6424 \gamma_{O}+0.7997 \gamma_{N}\right)}
$$

The relations (5) and (6) are the basic formulas that enable one to calculate the specific volume of dry flue gas under normal conditions and standard $\mathrm{O}_{2}$ content and the concentration of the sulfur dioxide in them by the data of the elemental fuel composition in the presence of unburnt carbon factor.

To simplify the calculations, we propose to replace the relations (5) and (6) by engineering formulas such as:

$$
\begin{gathered}
V_{G d}\left(q_{4}\right)=1.4\left(8.893 \gamma_{C}+20.9724 \gamma_{H}+3.319 \gamma_{S}-2.6424 \gamma_{O}+0.7997 \gamma_{N}\right)\left(1-\frac{q_{u}}{100}\right) \\
C_{S O 2}\left(q_{4}\right)=\frac{10^{6} \cdot 2 \gamma_{S}\left(1-\eta_{I}\right)\left(1-\eta_{I I} \beta\right)}{1.4\left(8.893 \gamma_{C}+20.9724 \gamma_{H}+3.319 \gamma_{S}-2.6424 \gamma_{O}+0.7997 \gamma_{N}\right)}\left(\frac{1}{1-\frac{q_{u}}{100}}\right)
\end{gathered}
$$

However, under actual conditions the lots of coal, which are supplied to the TPPs and CHPs, are accompanied only by the data of technical analysis, where the following characteristics are given: moisture content $W_{t}^{r}, \%$, ash content $A^{d}, \%$, and sulfur content $S^{d}, \%$, (as dry), lower heating value $Q_{i}^{r}$. The data of technical analysis do not enable one to calculate directly the specific volumes of dry flue gas and $\mathrm{SO}_{2}$ concentration in them. 


\section{- Processes and Equipment of Food Productions -}

Therefore, our method of calculating the expected specific volumes of dry flue gas and $\mathrm{SO}_{2}$ concentration sulfur uses only the data of the technical analysis.

The calculations of the specific volumes of the dry flue gas and concentrations of the sulfur dioxide are made following the data of 96 certificates for coal products from mines and processing plants of Donetsk coal basin, for samples of high-reactive and low-reactive coals. The given certificates are drawn up and approved by the Ukrainian Coal Reaching Institute, Luhansk. The elemental composition for each fuel sample was determined on the basis of such certificates. In the Certificate in particular the characteristics are defined, as follows: the coal rank, the production name (class), the volatile content $V^{d a f}$ (as dry ash free), $\%$, the ash content $A^{d}$ (as dry), $\%$, the total sulfur $S_{t}^{d}, \%$, higher heating value $Q_{i}^{d a f}$, $\mathrm{MJ} / \mathrm{kg}$, the total moisture content $W_{t}^{r}, \%$, the pyritic sulfur $S_{p}{ }^{d}, \%$, the sulfate sulfur $S_{s}^{d}, \%$, the low heat value, the organic carbon $C^{d a f}, \%$, the organic hydrogen to $H^{d a f}, \%$, the organic sulfur $S_{o}^{d a f}, \%$, the nitrogen and oxygen $(N+O)^{d a f}, \%$, etc. I.e., the calculations were carried out in according the standard procedure as per formulas (1)-(4) following the present certificates.

The results of the calculation of the specific volume of the dry flue gas for the samples of the high-reactive and low-reactive coal provided full fuel burn-up $\left(q_{4}=0\right)$ are shown in Figure 1 and Figure 2.

It is specified, that the dependence of the specific volume of the dry flue gas $V_{G d}$, $\mathrm{m}_{\mathrm{n}}^{3} / \mathrm{kg}$, from the fuel lower heating value $Q_{i}^{r}, \mathrm{MJ} / \mathrm{kg}$, has linear character (Fig.1):

$$
V_{G d}=K Q_{i}^{r} \text {, (9) }
$$

where $K$ - the factor that depends on coal metamorphism degree, $\mathrm{m}_{\mathrm{n}}{ }^{3} / \mathrm{MJ}$.

The $K$ values for bituminous coal and separately for high-reactive (B, SB) and lowreactive (A, SA) coals, are determined. The factor received by us, are well agreed with sources published. Specifically, the $K=0.358 \mathrm{~m}_{\mathrm{n}}{ }^{3} / \mathrm{MJ}$ is used for the high-reactive coal in the National Emission Reduction Plans (NERP) of the Limited Gross Emissions Calculation Rules.

The value of the $K$ factor for high-reactive Donetsk coals is similar to European value. For coal-fired boilers that burn low-reactive Donetsk coals, to calculate the volume of dry flue gas need to use the local factor $K=0.368 \mathrm{~m}_{\mathrm{n}}{ }^{3} / \mathrm{MJ}$. The difference in the $K$ values for the high-reactive and low-reactive coals could be explained by high content of hydrogen and oxygen in the high-reactive coals in comparison with the low-reactive coals. Therefore, lower values of the specific volumes of dry flue gas are typical for the high-reactive fuel (see the Figure 1). 


$$
V_{G d}, \mathbf{m}_{\mathbf{n}}{ }^{3} / \mathbf{k g}
$$

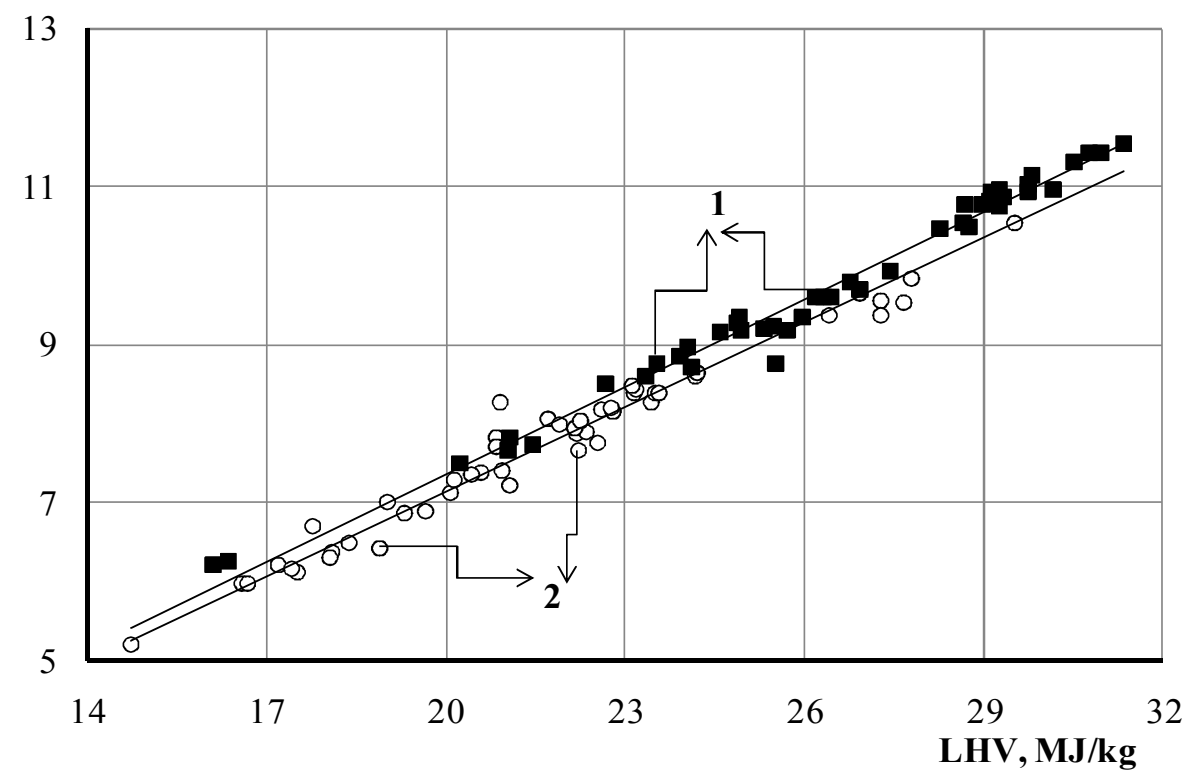

Figure 1. The dependence of the specific volume calculated of the dry flue gas formed under coal combustion, from lower heating value (LHV) of the fuel: 1 - low-reactive coal (A, SA), 2 high-reactive coal $(B, S B)$

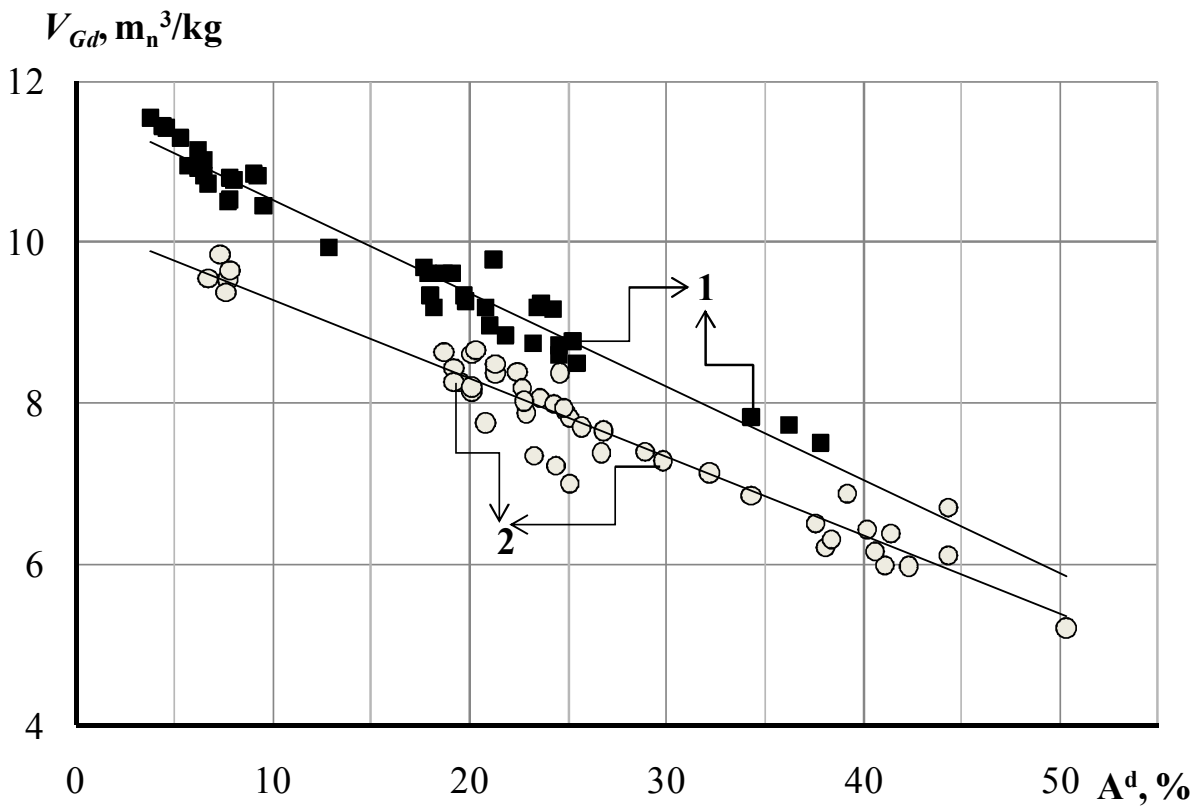

Figure 2. The dependence of the specific volume calculated of the dry flue gas formed under coal combustion, from ash content: 1 - low-reactive coal (A, SA), 2 - high-reactive coal (B, SB) 
Table 1

The empirical dependencies of the factor $K$ from the lower heating value of fuel for different types of coal

\begin{tabular}{|c|c|c|}
\hline & Type of coal & $K, \mathbf{m}_{\mathbf{n}}{ }^{3} / \mathbf{M J}$ \\
\hline & Coal, & $0.363 *$ \\
\hline & including low-reactive coal (A, SA) & $0.368 * *$ \\
\hline & high-reactive coal $(\mathrm{B}, \mathrm{SB})$ & $0.357 * * *$ \\
\hline
\end{tabular}

The dependence of the specific dry flue gas volume $V_{G d}, \mathrm{~m}_{\mathrm{n}}{ }^{3} / \mathrm{kg}$, from the ash content in coal $A^{d}$ (as dry): $V_{G d}=a+b A^{d}$ is being of interest for practical using. With this, the values of $a$ and $b$ approximation coefficients will be also different for low-reactive and highreactive coal (Table 2). Obviously, the reduction of the dry flue gas volume during ash content increasing - the proportion of the organic component of the coal is decreased (Figure 2).

Table 2

The empirical dependencies of the specific volume of the dry flue gas from the ash-content of the coal for different types of coal

\begin{tabular}{|c|c|}
\hline Coal grade & Dependence \\
\hline Low-reactive coal $(\mathrm{A}, \mathrm{SA})$ & $V_{G d}=11.70-0.12 A^{d}, \delta<1.9 \%$ \\
\hline High-reactive coal $(\mathrm{B}, \mathrm{SB})$ & $V_{G d}=10.20-0.10 A^{d}, \delta<3.1 \%$ \\
\hline
\end{tabular}

The empirical dependence of the calculation through calorific value of fuel $V_{G d}=K Q_{i}^{r}$ is proposed to use for calculations of specific volumes of dry flue gas. The empirical dependence of the calculation through the ash content $V_{G d}=a+b A$ is recommend for using as evaluation.

Also, the empirical dependencies of the sulfur dioxide concentration in the dry flue gas $C_{\mathrm{SO} 2}, \mathrm{mg} / \mathrm{m}_{\mathrm{n}}{ }^{3}$, were obtained from the sulfur content $S^{d}$ and ash content $A^{d}$ in the fuel for two groups of the coals - high-reactive coals (B, SB) and low-reactive coals (A, SA) which are well approximated by the dependence type

where $a$ and $b$ are the approximation coefficients.

$$
C_{S O 2}=S^{d}\left(a A^{d}+b\right)
$$

Such dependencies are shown in Table 3 for two groups of coal mentioned and boiler type (slag removal type) provided full fuel burnout $\left(q_{u}=0\right)$ [3]. The dependencies are given for the event of the non-availability of desulfurization facilities. 
The dependencies of the $\mathrm{SO}_{2}$ concentration in dry flue gas, $\mathrm{mg} / \mathrm{m}_{\mathrm{n}}{ }^{3}$

\begin{tabular}{|c|c|c|}
\hline Coal boiler & Low-reactive coal & High-reactive coal \\
\hline Dry Bottom Boiler & $\begin{array}{c}C_{S O 2}=S^{d}\left(1400+24 A^{d}\right), \\
\delta<1.9 \%\end{array}$ & $\begin{array}{c}C_{S O 2}=S^{d}\left(1350+31 A^{d}\right) \\
\delta<2.6 \%\end{array}$ \\
\hline Wet Bottom Boiler & $\begin{array}{c}C_{S O 2}=S^{d}\left(1500+25 A^{d}\right), \\
\delta<1.7 \%\end{array}$ & $\begin{array}{c}C_{S O 2}=S^{d}\left(1450+32 A^{d}\right) \\
\delta<2.7 \%\end{array}$ \\
\hline
\end{tabular}

For practical verification of the accounting the heat loss due unburnt carbon $q_{u}$ for determinations of the specific dry flue gas volume and $\mathrm{SO}_{2}$ concentration, the calculations following the formulas (5), (6) and (7), (8) for all 96 types of coal products were made. The calculations show that such formulas give similar values with relative error less than $0.6 \%$ at values $q_{4}$ to $10.0 \%$.

The heat loss due unburnt carbon $q_{u}$ leads to reduction of the specific volume of the dry flue gas and to increase of the sulfur dioxide concentration expected in dry flue gas in $1 /(1$ $\left.-q_{u} / 100\right)$ times in comparison with full fuel burnout, respectively. To account the unburnt carbon availability $\left(q_{\mathrm{u}}>0\right)$, it is proposed to use the dependencies: $V_{G d}\left(q_{u}\right)=V_{G d}(1-$ $\left.q_{u} / 100\right)$ and $C_{\mathrm{SO}_{2}}\left(q_{u}\right)=C_{\mathrm{SO} 2} /\left(1-q_{u} / 100\right)$.

The developed engineering method of the specific emissions calculation of the dry flue gas at the TPPs and CHPs and sulfur dioxide concentration in it is proposed to use in a range of the fuel ash content $A^{d}$ from 4.0 to $50.0 \%$ and lower heating value of fuel $Q_{i}^{r}$ from 14.5 to $32.0 \mathrm{MJ} / \mathrm{kg}$.

The calculations of the specific and gross emissions of the dry flue gas at the TPPs of Ukraine and sulfur dioxide concentration in it since 2012-2016 were carried out following the method developed. The information on quality, coal consumption that is supplied at TPP and $q_{u}$ from TPP official statistical reports were used for calculations. The calculations results for the coal-fired TPPs and 5 generation companies of Ukraine for 2012 are shown in Table 4. The values of the gross emissions of the dry flue gas and sulfur dioxide in dry flue gas obtained during the calculations are well coincide with the data represented by the TPPs and generating companies of Ukraine for 2012 (National Emission Reduction Plans (NERP) of the Limited Gross Emissions Calculation Rules).

The general results of the gross emissions' calculations of the dry flue gas and the sulfur dioxide concentrations in it at TPPs that burn low-reactive coal and at TPPs that burn highreactive coal since 2012-2016, are shown in Table 5. In last year's, the volume of the gross emissions of the sulfur oxide at the coal-fired TPPs of Ukraine reached 1000 thousand tons. The gross emission of the sulfur oxide decrease at the coal-fired TPPs of Ukraine up to 800 kilotons (kt) in 2015 is connected with the electricity production loss more than $30 \%$. In recent years, the values of the specific sulfur emissions at the coal-fired TPPs of Ukraine are at the level of the $16-20 \mathrm{~g} / \mathrm{kW}-\mathrm{h}$ of the electricity supplied against $1.2 \mathrm{~g} / \mathrm{kW}-\mathrm{h}$ of the electricity supplied - the today's average European level (following the data of the renew Energy Strategy of Ukraine till 2030). It is explained by using of coal with average and high sulfur content (see Tables 4, 5) at the TPPs of Ukraine and increasing the share of coal in the fuel balance of TPP. 
Table 4

The information on quality and coal consumption, the calculation results of the dry flue gas volume and sulfur dioxide specific and gross emissions at coal-fired TPPs of Ukraine, in 2012

\begin{tabular}{|c|c|c|c|c|c|c|c|c|c|c|c|c|c|}
\hline \multirow[b]{2}{*}{$\begin{array}{c}\text { Generating } \\
\text { Company/ } \\
\text { TPP }\end{array}$} & \multirow[b]{2}{*}{ 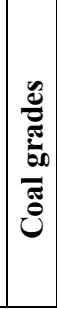 } & \multicolumn{3}{|c|}{ Coal quality } & \multirow[b]{2}{*}{ 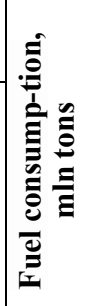 } & \multirow[b]{2}{*}{ ڤै. } & \multirow[b]{2}{*}{$q_{u}, \%$} & \multicolumn{4}{|c|}{$\begin{array}{c}\text { Calculation of the method } \\
\text { proposed }\end{array}$} & \multicolumn{2}{|c|}{ TPPs' data } \\
\hline & & \begin{tabular}{|l}
$\mathrm{LHV}$, \\
$\mathrm{MJ} / \mathrm{kg}$
\end{tabular} & $A^{d}, \%$ & $S^{d}, \%$ & & & & $\begin{array}{c}V_{G d} \\
\mathbf{m}_{\mathbf{n}}^{3} / \mathbf{k g}\end{array}$ & $\begin{array}{c}\mathrm{C}_{\mathrm{SO}_{2}}{ }^{2} \\
\mathrm{mg} / \mathbf{m}_{\mathbf{n}}{ }^{3}\end{array}$ & $\begin{array}{c}V_{G d}, \\
\text { bln } \\
\mathbf{m}^{3}\end{array}$ & $\begin{array}{c}\text { SO }_{2} \\
\mathbf{k t}\end{array}$ & $\begin{array}{c}V_{G d}, \\
\text { bln } \\
\mathbf{m}^{3}\end{array}$ & $\begin{array}{c}\text { SO }_{2} \\
\mathbf{k t}\end{array}$ \\
\hline \multicolumn{4}{|c|}{ PJSC Donbasenergo } & $\underline{1.47}$ & $\underline{4.38}$ & & & & & $\underline{33.3}$ & $\underline{107.6}$ & $\underline{32.7}$ & $\underline{92.7}$ \\
\hline Starobeshivska & \begin{tabular}{|l|} 
A \\
SA
\end{tabular} & 22.04 & 24.1 & 1.45 & 3.03 & WBB & 4.12 & 7.55 & 3172.5 & 22.9 & 72,7 & 22.3 & 57.4 \\
\hline Slov'yanska & $\mathrm{A}$ & 22.16 & 23.5 & 1.53 & 1.34 & WBB & 4.70 & 7.77 & 3348.4 & 10.4 & 34,9 & 10.4 & 35.2 \\
\hline \multicolumn{4}{|c|}{ PJSC Centerenergo } & $\underline{2.21}$ & $\underline{8.30}$ & & & & & $\underline{66.0}$ & $\underline{325,5}$ & $\underline{70.9}$ & $\underline{311.1}$ \\
\hline Vuhlehirska & \begin{tabular}{c|} 
B \\
SB
\end{tabular} & 22.57 & 22.9 & 3.22 & 2.60 & WBB & 0.17 & 8.29 & 7195.7 & 21.5 & 154.8 & 21.4 & 143.2 \\
\hline Trypilska & \begin{tabular}{|l|} 
A, \\
SA \\
\end{tabular} & 22.82 & 23.9 & 1.53 & 2.56 & WBB & 0.36 & 8.63 & 3418.7 & 19.6 & 66.9 & 18.2 & 68.2 \\
\hline Zmiyvska & $\begin{array}{r}\text { A } \\
\text { SA } \\
\end{array}$ & 23.03 & 23.6 & 1.92 & 3.14 & WBB & 3.50 & 7.93 & 4170.8 & 24.9 & 103.8 & 31.4 & 99.7 \\
\hline \multicolumn{4}{|c|}{ PJSC DTEK Dniproenergo } & $\underline{1.83}$ & $\underline{7.90}$ & & & & & $\underline{62.6}$ & $\underline{258.0}$ & $\underline{62.0}$ & $\underline{306}$ \\
\hline Kryvorizka & SA & 24.35 & 23.2 & 2.14 & 3.75 & WBB & 3.85 & 8.36 & 4634.4 & 31.3 & 145.2 & 27.7 & 175.5 \\
\hline Prydniprovska & $\begin{array}{c}\mathrm{A} \\
\mathrm{SA} \\
\end{array}$ & 22.56 & 25.1 & 1.29 & 1.99 & WBB & 9.00 & 7.33 & 3011.8 & 14.5 & 43.8 & 16.5 & 54.6 \\
\hline Zaporizka & \begin{tabular}{|c|}
$\mathrm{B}$ \\
$\mathrm{SB}$ \\
\end{tabular} & 21.08 & 25.2 & 1.78 & 2.17 & WBB & 0.38 & 7.73 & 4122.6 & 16.7 & 69.0 & 17.9 & 76.1 \\
\hline \multicolumn{4}{|c|}{ PJSC DTEK Zakhidenergo } & $\underline{1.88}$ & 8.09 & & & & & $\underline{62.8}$ & $\underline{264.6}$ & $\underline{55.2}$ & $\underline{232.6}$ \\
\hline Burshtynska & \begin{tabular}{|c|} 
B \\
SB \\
\end{tabular} & 21.33 & 22.6 & 1.97 & 4.70 & WBB & 1.22 & 7.75 & 4426.6 & 36.4 & 161.3 & 33.3 & 138.7 \\
\hline Dobrotvirska & \begin{tabular}{|c|}
$\mathrm{B}$ \\
$\mathrm{SB}$ \\
\end{tabular} & 22.44 & 24.1 & 2.09 & 1.14 & DBB & 1.09 & 8.17 & 4539.2 & 9.3 & 42.2 & 7.4 & 35.5 \\
\hline Ladyzhynska & $\begin{array}{r}\text { B } \\
\text { SB } \\
\end{array}$ & 20.73 & 23.0 & 1.59 & 2.25 & WBB & 0.43 & 7.60 & 3571.9 & 17.1 & 61.1 & 14.4 & 58.4 \\
\hline \multicolumn{4}{|c|}{ LLC DTEK Skhidenergo } & $\underline{1.68}$ & $\underline{8.80}$ & & & & & $\underline{63.3}$ & $\underline{251.2}$ & $\underline{66.1}$ & $\underline{243.4}$ \\
\hline Zuivska & $\begin{array}{r}\text { B } \\
\text { SB } \\
\end{array}$ & 19.22 & 30.1 & 1.93 & 2.63 & WBB & 0.30 & 7.05 & 4756.6 & 18.5 & 88.2 & 19.6 & 85.4 \\
\hline Kurakhivska & \begin{tabular}{|c|} 
B \\
SB \\
\end{tabular} & 17.67 & 36.9 & 1.67 & 3.42 & DBB & 2.04 & 6.37 & 4323.6 & 21.8 & 94.3 & 22.3 & 91.5 \\
\hline Luhanska & $\begin{array}{r}\mathrm{A}, \\
\mathrm{SA}\end{array}$ & 24.43 & 18.7 & 1.46 & 2.75 & WBB & 4.11 & 8.36 & 2991.5 & 23.0 & 68.7 & 23.9 & 66.4 \\
\hline Total & & & & $\underline{1.85}$ & $\underline{37.46}$ & & & & & $\underline{288.1}$ & 1207.0 & 287.0 & $\underline{1186.0}$ \\
\hline
\end{tabular}


Table 5

Information on installed capacity, power supply, quality and consumption of coal and the calculation results of the dry flue gas' and sulfur dioxide specific and gross emissions at coalfired TPPs of Ukraine since 2012-2016

\begin{tabular}{|c|c|c|c|c|c|c|c|c|c|}
\hline \multirow[b]{2}{*}{ TPP } & \multirow{2}{*}{$\begin{array}{l}\text { Installed } \\
\text { capacity, } \\
\text { mln } \mathbf{k W}\end{array}$} & \multirow{2}{*}{$\begin{array}{c}\text { Power } \\
\text { supply, } \\
\text { TWh }\end{array}$} & \multicolumn{3}{|c|}{ Coal quality } & \multirow{2}{*}{$\begin{array}{c}\text { Fuel } \\
\text { consumption, } \\
\text { mIn tons }\end{array}$} & \multirow{2}{*}{$\begin{array}{c}V_{G d}, \\
\text { bln } \mathbf{m}^{3}\end{array}$} & \multirow[b]{2}{*}{$\begin{array}{c}c_{S_{S O 2},} \\
\text { kt }(\%)\end{array}$} & \multirow{2}{*}{$\begin{array}{c}\mathrm{SO}_{2}, \\
\mathrm{~g} / \mathbf{k W} \\
-\mathrm{h}\end{array}$} \\
\hline & & & $\begin{array}{c}\mathrm{Q}_{\mathrm{i}}^{\mathrm{r}}, \\
\mathbf{M J} / \mathbf{k g}\end{array}$ & $\mathbf{A}^{\mathrm{d}}, \%$ & $S^{d}, \%$ & & & & \\
\hline \multicolumn{10}{|c|}{2012} \\
\hline Total & 21.73 & 71.7 & & & $1.85^{*}$ & 37.46 & 288.1 & 1207.0 & 16.8 \\
\hline $\begin{array}{r}\text { of which } \\
\text { A, SA } \\
\end{array}$ & $12.06(55.5 \%)$ & $\begin{array}{c}36.7 \\
(51.2 \%) \\
\end{array}$ & 23.2 & 23.1 & $1.7 \mid 1$ & $18.56(49.5 \%)$ & 146.6 & $\begin{array}{c}536.0 \\
(44.4 \%) \\
\end{array}$ & 14.6 \\
\hline B, SB & $9.67(44.5 \%)$ & $\begin{array}{c}35.0 \\
(48.8 \%)\end{array}$ & 20.5 & 26.1 & 2.01 & $18.90(50.5 \%)$ & 141.5 & $\begin{array}{c}671.0 \\
(55.6 \%)\end{array}$ & 19.2 \\
\hline \multicolumn{10}{|c|}{2013} \\
\hline Total & 21.94 & 71.1 & & & $1.93^{*}$ & 36.85 & 286.1 & 1244.6 & 17.5 \\
\hline $\begin{array}{l}\text { of which } \\
\text { A, SA }\end{array}$ & $12.21(55.6 \%)$ & $\begin{array}{c}34.7 \\
(48.9 \%)\end{array}$ & 23.3 & 22.7 & \begin{tabular}{|l|l}
1.83 & 1
\end{tabular} & $17.78(48.3 \%)$ & 140.3 & $\begin{array}{c}562.1 \\
(45.2 \%)\end{array}$ & 16.2 \\
\hline $\mathrm{B}, \mathrm{SB}$ & $9.73(44.4 \%)$ & $\begin{array}{c}36.4 \\
(51.1 \%) \\
\end{array}$ & 20.9 & 24.6 & 2.041 & $19.07(51.8 \%)$ & 145.8 & $\begin{array}{c}682.5 \\
(54.8 \%) \\
\end{array}$ & 18.8 \\
\hline \multicolumn{10}{|c|}{2014} \\
\hline Total & 22.30 & 62.0 & & & $1.82 *$ & 32.52 & 251.0 & 1038.0 & 16.7 \\
\hline $\begin{array}{c}\text { of which } \\
\text { A, SA }\end{array}$ & $12.44(55.8 \%)$ & $\begin{array}{c}28.5 \\
(46.0 \%) \\
\end{array}$ & 23.4 & 22.2 & 1.68 & $14.52(44.7)$ & 114.8 & $\begin{array}{c}423.5 \\
(40.8 \%)\end{array}$ & 14.8 \\
\hline B, SB & $9.86(44.2 \%)$ & $\begin{array}{c}33.5 \\
(54.0 \%)\end{array}$ & 20.8 & 27.4 & 1.93 & $18.0(55.3)$ & 136.2 & $\begin{array}{c}614.5 \\
(59.2 \%) \\
\end{array}$ & 18.4 \\
\hline \multicolumn{10}{|c|}{2015} \\
\hline Total & 22.36 & 49.0 & & & $1.73^{*}$ & 26.70 & 202.1 & 818.2 & 16.7 \\
\hline $\begin{array}{r}\text { of which } \\
\text { A, SA } \\
\end{array}$ & $12.49(55.9 \%)$ & $\begin{array}{c}15.6 \\
(31.7 \%) \\
\end{array}$ & 23.0 & 24.2 & $1.72 \xi$ & $8.36(31.3 \%)$ & 66.5 & $\begin{array}{c}249.7 \\
(30.5 \%) \\
\end{array}$ & 16.0 \\
\hline $\mathrm{B}, \mathrm{SB}$ & $9.87(44.1 \%)$ & $\begin{array}{c}33.4 \\
(68.3 \%)\end{array}$ & 20.2 & 28.7 & 1.741 & $18.35(68.7 \%)$ & 136.6 & $\begin{array}{c}568.5 \\
(69.5 \%)\end{array}$ & 17.0 \\
\hline \multicolumn{10}{|c|}{2016} \\
\hline Total & 22.34 & 52.7 & & & 1.91 & 29.42 & 224.7 & 993.5 & 18.8 \\
\hline $\begin{array}{c}\text { of which } \\
\text { A, SA }\end{array}$ & $12.44(55.7 \%)$ & $\begin{array}{c}21.4 \\
(40.7 \%) \\
\end{array}$ & 23.7 & 23.4 & 2.0 & $12.3(41.8 \%)$ & 97.2 & $\begin{array}{c}430.0 \\
(43.3 \%) \\
\end{array}$ & 20.0 \\
\hline $\mathrm{B}, \mathrm{SB}$ & $9.90(44.3 \%)$ & $\begin{array}{c}31.3 \\
(59.3 \%)\end{array}$ & 19.9 & 28.9 & 1.85 & \begin{tabular}{l|l}
35 & $17.1(58.2 \%)$
\end{tabular} & 127.5 & $\begin{array}{c}563.5 \\
(56.7 \%)\end{array}$ & 18.0 \\
\hline
\end{tabular}

Besides, the service operation of coal-fired TPPs' power units took place on the basis of the obsolete process flow sheets that were developed in the 1960s. As of January 1, 2017, among 88 coal-fired TPPs' power units of Ukraine, 67 power units with a total installed capacity of 15.5 million $\mathrm{kW}(69.5 \%)$ were in operation for 250 thousand hours. Furthermore, 4 power units with an installed capacity 1.1 million $\mathrm{kW}(4.9 \%)$ were removed from service. The wear of equipment leads to fuel over-expenditure, decrease in the working power, and worsening of the ecological parameters. The average efficiency of these power units is about $31 \%$ (for comparison $-45 \%$ at operation under the base regime 
in the developed countries). In this regard, high specific expenditures of the reference fuel are observed: in 2015 , they were $400.8 \mathrm{~g}$ of coal equivalent per $1 \mathrm{~kW}-\mathrm{h}$ of electricity supplied and, in 2016, $403.7 \mathrm{~g}$ of coal equivalent per $1 \mathrm{~kW}-\mathrm{h}$.

The power units are equipped with the dust collectors only, none of the TPP has the plants of flue gas cleaning from sulfur dioxide and nitrogen oxides emissions. Moreover, the Ukrainian TPPs are mainly equipped with wet bottom boilers (see Table 4), the efficiency of the sulfur retention of which is $5 \%$.

It should be noted, that the implementation of the Directive 2010/75/EU on industrial emissions is foreseen the sulfur oxide emissions reduction at the coal-fired TPPs and CHPs of Ukraine up to $56 \mathrm{kt}$, in 2033.

Using the developed method, we also performed calculations of the specific and gross volumes of dry flue gases at the Darnytska Combined Heat and Power Plant (CHP) and sulphur dioxide concentration in them in 2008-2015. In Table 6, we present the results of these calculations.

Table 6

Data on the quality and consumption of coal (grade A) and results of the calculations of the specific and gross volumes of dry flue gases and sulphur dioxide emission at the Darnytska CHP in 2008-2015

\begin{tabular}{|c|c|c|c|c|c|c|c|c|c|}
\hline \multirow[b]{2}{*}{ Years } & \multicolumn{3}{|c|}{ Coal quality } & \multirow{2}{*}{$\begin{array}{c}\text { Fuel } \\
\text { consump- } \\
\text { tion, kt }\end{array}$} & \multirow[b]{2}{*}{$\begin{array}{l}\text { Part in fuel } \\
\text { balance, \% }\end{array}$} & \multirow[b]{2}{*}{$\begin{array}{c}V_{G d}, \\
\mathbf{m}_{\mathbf{n}}{ }^{3} / \mathbf{k g}\end{array}$} & \multirow{2}{*}{$\begin{array}{c}\mathrm{C}_{\mathrm{SO}_{2}}{ }{ }^{3}{ }^{\mathrm{mg} / \mathrm{m}_{\mathrm{n}}{ }^{3}}\end{array}$} & \multirow[b]{2}{*}{$\begin{array}{c}V_{G d}, \\
\text { bln } \mathbf{m}^{3}\end{array}$} & \multirow{2}{*}{$\begin{array}{c}\text { SO }_{2} \\
\text { kt }\end{array}$} \\
\hline & $\begin{array}{l}\text { LHV, } \\
\text { MJ/kg }\end{array}$ & $\begin{array}{l}\mathrm{A}^{\mathrm{d}}, \\
\%\end{array}$ & $\begin{array}{l}S^{\mathbf{d}}, \\
\%\end{array}$ & & & & & & \\
\hline 2008 & 21.36 & 25.08 & 1.32 & 138.51 & 40.2 & 7.08 & 3119.6 & 0.98 & 3.06 \\
\hline 2009 & 21.95 & 22.70 & 1.45 & 163.85 & 44.0 & 7.27 & 3331.0 & 1.19 & 3.97 \\
\hline 2010 & 22.66 & 20.49 & 1.52 & 182.89 & 42.3 & 7.51 & 3398.5 & 1.37 & 4.67 \\
\hline 2013 & 22.86 & 21.23 & 1.62 & 452.87 & 58.9 & 7.57 & 3655.3 & 3.43 & 12.54 \\
\hline 2014 & 23.27 & 20.22 & 1.38 & 459.04 & 65.7 & 7.71 & 3075.1 & 3.54 & 10.88 \\
\hline 2015 & 22.80 & 22.59 & 1.11 & 378.79 & 61.9 & 7.55 & 2546.5 & 2.89 & 7.28 \\
\hline
\end{tabular}

At present, six steam drum wet bottom boilers of high pressure work at the Darnytska CHP. All steam boilers were designed for the burning of coal of grade A.

It is worth noting that the Darnytska CHP is located in the industrial zone of Darnytska district of the city of Kyiv, at Khotkevycha Hnata str., 20. The nearest dwelling building is located to the south-west direction at a distance of $600-800 \mathrm{~m}$ from the main sources of emission. During the recent years, the average daily emission of sulfur dioxide is $20-35 \mathrm{t}$. The Darnytska CHP is the significant contaminant of environment in Kyiv.

\section{Conclusions}

1. We developed an engineering method for determining the specific volume of dry flue gases and expected sulfur dioxide concentration in coal-fired boilers under normal conditions, based on the data of fuel technical analysis.

2. We obtained empirical linear dependencies of the specific volume of dry flue gases on lower heating value and ash content in the fuel. These dependences are different for low-reactive and high-reactive coals. 


\section{- Processes and Equipment of Food Productions-}

3. Empirical linear dependencies of the expected sulfur dioxide concentrations on the values of sulfur and ash content in the fuel for low-reactive and high-reactive coals were derived.

4. It is shown that, in the presence of unburned carbon the specific volume of dry flue gases decreases by a factor of $1 /\left(1-q_{\mathrm{u}} / 100\right)$, and sulfur dioxide concentration grow in the same proportion.

5. According to the obtained dependences were calculated the volumes of dry flue gases and gross $\mathrm{SO}_{2}$ emissions at Ukrainian thermal power plants in 2012-2016. The values of specific sulfur dioxide emission in recent years are at the level of $16-20 \mathrm{~g} / \mathrm{kW}-\mathrm{h}$ of electricity supplied, which is $13-15$ times higher than the average European level.

\section{References}

1. Volchyn I., Dunayevska N., Haponych L., Chernyvskyi M., Topal O., Zasyadko Ya. (2013), Prospects for the implementation of clean coal technologies in the energy sector of Ukraine, GNOZIS, Kyiv.

2. Lipov Ju. M., Tret'jakov Ju. M. (2003), Kotel'nye ustanovki i parogeneratory, NIC Reguljarnaja i haoticheskaja dinamika, Moskow.

3. Volchyn I., Haponych L. (2014), Estimate of the sulfur dioxide concentration at thermal power plants fired by Donetsk coal, Power Technology and Engineering, 48(3), pp. 218-221.

4. Stanislaw Hlawiczka, Katarzyna Korszun, Janina Fudala (2016), Acidity of vapor plume from cooling tower mixed with flue gases emitted from coal-fired power plant, Science of The Total Environment, 554-555, pp. 253-258.

5. Kyeongsook Kim, Seugran Yang, Joong Beom Lee, Tae Hyoung Eom, Chong Kul Ryu, Sung-Ho Jo, Young Cheol Park, Chang-Keun Yi (2012), Analysis of K2CO3/Al2O3 CO2 sorbent tested with coal-fired power plant flue gas: Effect of Sox, International Journal of Greenhouse Gas Control, 9, pp. 347-354.

6. Patricia Córdoba (2015), Status of Flue Gas Desulphurisation (FGD) systems from coal-fired power plants: Overview of the physic-chemical control processes of wet limestone FGDs, Fuel, 144, pp. 274-286.

7. Yang Ou, Haibo Zhai, Edward S. Rubin (2016), Life cycle water use of coal- and natural-gas-fired power plants with and without carbon capture and storage, International Journal of Greenhouse Gas Control, 44, pp. 249-261.

8. Paul Breeze (2014), Chapter 3 - Coal-fired Power Plants, Power Generation Technologies (Second Edition), pp. 2-65

9. Paul Breeze (2016), Chapter 9 - Gas-Fired Power Plants and the Environment, GasTurbine Power Generation, pp. 83-92 